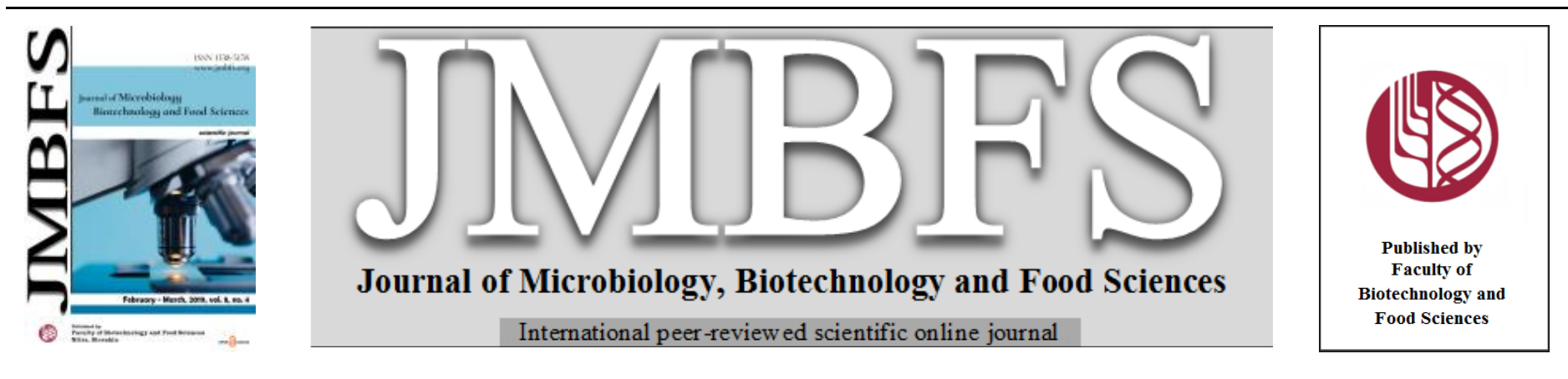

\title{
EFFECT OF ESSENTIAL OILS OF LAMIACEAE PLANTS ON THE PENICILLIUM COMMUNE
}

\author{
Dana Tančinová*1, Juraj Medo ${ }^{1}$, Zuzana Mašková ${ }^{1}$, Denisa Foltinovál, Július Árvay ${ }^{2}$ \\ Address(es): prof. Ing. Dana Tančinová, PhD. \\ ${ }^{1}$ Slovak University of Agriculture, Faculty of Biotechnology and Food Sciences, Department of Microbiology, Tr. A. Hlinku 2, 94976 Nitra, Slovakia. \\ ${ }^{2}$ Slovak University of Agriculture, Faculty of Biotechnology and Food Sciences, Department of Chemistry, Tr. A. Hlinku 2, 94976 Nitra, Slovakia.
}

*Corresponding author: dana.tancinova@uniag.sk

doi: 10.15414/jmbfs.2019.8.4.1111-1117

\section{ARTICLE INFO}

Received 9. 8. 2018

Revised 16.11.2018

Accepted 13. 12. 2018

Published 1. 2. 2019

Regular article OPEN $\partial_{\text {ACCESS }}$

\begin{abstract}
The aim of this research was to determine the inhibitory effect of vapor phase of eight essential oils (EOs) on the growth of seven strains of Penicillium commune isolated from moldy milk products. Another objective was to determine the minimum inhibitory doses (in vitro and probit analyses) of EOs, which at concentration $625 \mu \mathrm{L} \cdot \mathrm{L}^{-1}$ of air completely inhibited the growth of all strains. The antifungal activity was evaluated by the micro-atmosphere method. Thyme, red thyme, peppermint, mint, and savory completely inhibited the growth of strains during cultivation at $25^{\circ} \mathrm{C}$ and $5{ }^{\circ} \mathrm{C}$. Basil, rosemary, and sage EOs have different effects on the growth of $P$. commune strains. EOs that completely inhibit the growth of all strains were used to determine their minimum inhibitory doses (MIDs). The best results $62.5 \mu \mathrm{L} . \mathrm{L}^{-1}$ of air and $125 \mu \mathrm{L} \cdot \mathrm{L}^{-1}$ of air $7^{\text {th }}$ day at $25^{\circ} \mathrm{C}$ of incubation showed red thyme EO. Similar results were also found in thyme EO, but the MID inhibiting the growth of the one strain was $250 \mu \mathrm{L} . \mathrm{L}^{-1}$ of air. MIDs of savory and peppermint were from 125 to $500 \mu \mathrm{L} . \mathrm{L}^{-1}$ of air. Mint EO had the highest MID (from 250 to $625 \mu \mathrm{L} \cdot \mathrm{L}^{-1}$ of air). On the $14^{\text {th }}$ day of incubation we found the same MIDs, respectively higher. It was found that EOs have different effects on individual strains of $P$. commune. According to probit analyses, the most effective tested EOs were red thyme and thyme, less effective peppermint and savory, and the least effective was mint EO.
\end{abstract}

Keywords: $P$. commune, essential oils, antifungal activity, vapor phase

\section{INTRODUCTION}

Molds are the most common cheese spoilage organisms which can lead to economic loss as well as raising public health concerns due to the production of mycotoxins (Cheong et al., 2014). According to Pitt and Hocking (2009), cheese is very susceptible to mold growth. Spoilage is generally confined to molds which are psychrotolerant. Lund $\boldsymbol{e t}$ al. (1995) reported that $91 \%$ of isolates from cheeses from Denmark, France, Greece, UK and other countries were Penicillium species. Penicillium commune was the most widespread and most frequent occurring ( $42 \%$ ) species. P. commune is one of the most important cheese contaminant (Kure and Skaar, 2000; Kure et al., 2001, Garnier et al., 2017). The growth of $P$. commune on cheese results in discoloring of the surface and production of off flavors. In spite of the fact that the dairy staff daily clean and disinfect the production plants and environments, periodical growth of $P$. commune on cheese is a major problem (Lund et al., 2003).

Today's consumers demand food that is minimally technologically processed and without synthetic preservatives or additives, because of the possible adverse health effects. Therefore, the food industry is now focused on finding solutions that fully satisfy the criteria of consumers while retaining the food safety. Application of natural antimicrobial agents such as extracts, essential oils and components of spices, and other aromatic plants could be significant in resolving these problems. These agents may be useful as additives in limiting or preventing the development of harmful fungi in food, as food surface protectants, or in modified atmosphere packaging of food (Kocic-Tanackov et al., 2014). Essential oils have deserved much attention in the past decades for their antimicrobial activity, since many of them have demonstrated efficacy against food-borne pathogenic and spoilage microorganisms (Bassanetti et al., 2017).

The aim of the present research was to determine the inhibitory effect of vapor phase of eight essential oils on the growth of seven different strains of $P$. commune isolated from moldy milk products. Another objective was to determine the minimum inhibitory doses of essential oils, which at a concentration 625 $\mu L . L^{-1}$ of air completely inhibited the growth of all the strains.

\section{MATERIAL AND METHODS}

\section{Plant essential oils}

The essential oils used in this study were extract of basil (Oscimum basilicum L.), rosemary (Rosmarinus officinalis $\mathrm{L}$.), thyme and red thyme (Thymus vulgaris $\mathrm{L}$.), peppermint (Mentha piperita L.), mint (Mentha crispate L.) savory (Satureja hortensis L.), and sage (Salvia officinalis L.). Essential oils were commercially produced.

\section{Chemical composition of essential oils}

Semi-quantitative composition of the essential oil samples was determined by gas chromatography coupled with mass spectrometry (GC-MS) using an Agilent 7890B oven coupled with Agilent 5977A mass detector (Agilent Technologies Inc., Palo Alto, CA, USA) and CombiPal autosampler 120 (CTC Analytics AG, Zwingen, Switzerland). Prior to the analysis, essential oil samples were diluted in hexane (HPLC $\geq 97 \%$, Sigma Aldrich GmbH, Germany) to a concentration of 10 $\mu \mathrm{L} \mathrm{mL}^{-1}$. One microliter of diluted sample was injected in inlet operated in split mode $\left(1: 10 ; 250{ }^{\circ} \mathrm{C}\right)$. Separation was achieved using a ZB-WAXplusTM capillary column $(10 \mathrm{~m} \times 0.1 \mathrm{~mm} \times 0.10 \mu \mathrm{m})($ Phenomenex Inc., Torrance, $\mathrm{CA}$, USA) and the following oven temperature programme: $50{ }^{\circ} \mathrm{C}$ for the first 5 minutes, increased to $240{ }^{\circ} \mathrm{C}$ at the rate of $3{ }^{\circ} \mathrm{C} \mathrm{min}^{-1}$, and it was kept constant for 2 minutes. Helium was used as carrier gas at the constant flow $(1.2 \mathrm{~mL} \mathrm{~min}-1)$. The mass detector parameters were as follows: ionization energy of filament: 70 $\mathrm{eV}$, transfer line temperature: $250{ }^{\circ} \mathrm{C}$, MS source temperature: $230{ }^{\circ} \mathrm{C}$, quadrupole temperature: $150{ }^{\circ} \mathrm{C}$. The mass spectrometer was programmed under electron impact (EI) in a full scan mode at $\mathrm{m} / \mathrm{z}$ 40-400. The identification of compounds was carried out by comparing of mass spectra (over $80 \%$ match) with a commercial database NIST ${ }^{\circledR} 2014$ and the retention times of reference standards (nerol, linalool, geraniol, citral, $\alpha$-pinene and $\beta$-pinene). Semiquantitative content of determined compounds was calculated by dividing individual peak area (excluded by solvent peak area) by total area of all peaks. Peaks under $0.1 \%$ were not counted. 


\section{Fungal culture}

Seven strains (Table 1) from different moldy milk products were used. These strains belong to the Collection of Fungi of Department of Microbiology; Faculty of Biotechnology and Food Sciences SUA in Nitra, Slovakia. 5 day old cultures cultivated on Czapek yeast extract agar (CYA) at $25 \pm 1{ }^{\circ} \mathrm{C}$ were used for each experiment (CYA, Pitt et Hocking, 2009).

Table 1 Origin of the strains Penicillium commune

\begin{tabular}{lc}
\hline Strain & Origin \\
\hline$P$. commune KMi 177 & cheese flavored with pepper \\
\hline$P$. commune KMi 270 & smoked cheese (block) \\
\hline$P$. commune KMi 276 & smoked cheese (slices) \\
\hline$P$. commune KMi 277 & smoked cheese (slices) \\
\hline$P$. commune KMi 370 & sour cream \\
\hline$P$. commune KMi 402 & sour cream \\
\hline$P$. commune KMi 403 & parenica (pasta filata) \\
\hline
\end{tabular}

\section{Antifungal activity of essential oils}

The antifungal activity of selected essential oils was evaluated by the microatmosphere method. The test was performed in sterile plastic Petri dishes $(\varnothing 90$ $\mathrm{mm}$ ) containing $15 \mathrm{~mL}$ of CYA. The evaluation by filter paper was made by the adapted method from Guynot et al. (2003). Essential oils were tested in concentration $625 \mu \mathrm{L} . \mathrm{L}^{-1}$ of air. A round sterile filter paper $(\varnothing 9 \mathrm{~cm})$ was placed in the lid of Petri dish and $50 \mu \mathrm{L}$ of essential oil was pipetted by micropipette to the paper. Dishes were kept in inverted position. Filter paper discs impregnated with sterilized distilled water were used as a control. Each strain was inoculated in the center of Petri dishes with sterilized needle. Dishes were tightly sealed with parafilm and incubated for 14 days at $25 \pm 1{ }^{\circ} \mathrm{C}$ and for 35 days at $5 \pm 1{ }^{\circ} \mathrm{C}$ (four replicates were used for each treatment). The diameters (Ø $\mathrm{mm}$ ) of the growing colonies (from the reverse side) were measured at the $3^{\text {rd }}, 7^{\text {th }}, 11^{\text {th }}$, and $14^{\text {th }}$ day strains cultivated at $25 \pm 1{ }^{\circ} \mathrm{C}$ and $3^{\text {rd }}, 7^{\text {th }}, 11^{\text {th }}, 14^{\text {th }}, 21^{\text {st }}, 28^{\text {th }}$ and $35^{\text {th }}$ day cultivated at $5 \pm 1{ }^{\circ} \mathrm{C}$ with a digital caliper.

\section{Inhibition of mycelial growth}

According to Cakir et al. (2005) and Kordali et al. (2008), growth inhibition of treated samples (T) against control (C) was calculated by the percentage of growth inhibition using the following equation:

\section{$\%$ of inhibition $=(\mathrm{C}-\mathrm{T}) / \mathrm{C} \times 100$}

where, $\mathrm{C}$ is the mean of six replicates of hyphal extension $(\mathrm{mm})$ of controls and $\mathrm{T}$ is the mean of six replicates of hyphal extension $(\mathrm{mm})$ of plates treated with either essential oil.

\section{Minimum inhibitory doses (MIDs)}

Essential oils that completely inhibit the growth of all strains were used to determine their minimum inhibitory doses (MIDs). EOs dissolved in DMSO were prepared at different concentrations $(625,500,250,125,63,31.25$, and 15.63 $\mu \mathrm{L} . \mathrm{L}^{-1}$ of air). For each fungal strain, a conidial spore suspension of $10^{6}$ spore's $\mathrm{ml}^{-1}$ was prepared. Petri dishes ( $90 \mathrm{~mm}$, two-sector, three replicates) containing $15 \mathrm{~mL}$ of CYA were inoculated by $5 \mu 1$ spores suspension. Cultivation was carried out at the $25 \pm 1{ }^{\circ} \mathrm{C}$ and measured after 7 and 14 days. The MID (expressed as microliters of EOs per volume unit of atmosphere above the organism growing on the agar surface) was defined as the lowest concentration of the oil which did not permit any visible growth after 7 or 14 days in comparison with control sets.

\section{Probit analyses}

The ability of strains to grow in the presence of EO was coded to binomial scale ( 1 - growth observed, 0 - without growth). Such data were processed by probit analysis in Statgraphics Centurion XV (Statgraphics) software. Doses that inhibit the growth in $50 \quad \% \quad$ respectively $90 \%$ of cases (MID50 and MID90) were reversely predicted from regression equation.

\section{Statistical analysis}

Average diameters of developed colonies were compared using 2-factor ANOVA with interaction. Average values for strains as well as essential oils were compared using Tukey post hoc test. Analysis was performed in Statgraphics.

\section{RESULTS AND DISCUSSION}

In this study, evaluating the antifungal properties of eight essential oils from family Lamiaceae. Essential oils are complex mixtures of low molecular weight compounds extracted from plants by steam distillation and various solvents Terpenoids and phenylpropanoids are the major constituents, which provide characteristic aroma and biological properties to essential oils (Raut et Karuppayil, 2014). According to authors (Ben Farhat, et al., 2016; MéndezTovar et al., 2016; Dušková et al., 2016) the effect of the growing seasons, different growth stage of plants, and climatic conditions of each year in terms of the essential oil content and composition were proven. Based on the above, we also focused on the composition of the essential oils used. The GC-MS analyses of the essential oils led to identification of 98 compounds, 34 from them are presented in $\geq 1$ percentage amount in minimal one essential oil. The identified compounds (34) are listed in Table 2. The major components according to the concrete essential oil were: basil - Estragole (84.98\%); red thyme - Thymol $(33.65 \%)$ and o-xylene $(43.85 \%)$; rosemary - Eucalyptol (43.17\%), (+)-2 Bornanone $(12.80 \%)$ and $\alpha$-pinene $(10.74 \%)$; thyme - Thymol $(40.41 \%)$ and Benzene, 4-ethyl-1,2-dimethyl- (19.45\%); peppermint - Levomenthol (44.94\%) and menthone $(22.51 \%)$; savory - $\gamma$-Terpinene $(45.09 \%)$, Thymol $(20.20 \%)$ and p-Cymene $(19.64 \%)$; sage -Thujone $(22.37 \%),(+)-2$-Bornanone $(19.65 \%)$ and Eucalyptol (10.84\%); mint - (-)-Carvone (72.62\%) and D-Limonene (15.23 $\%)$.

Table 2 Essential oils tested for the fungicidal effect and their compounds [\%]* determined by gas chromatography coupled with mass spectrometry (GC-MS)

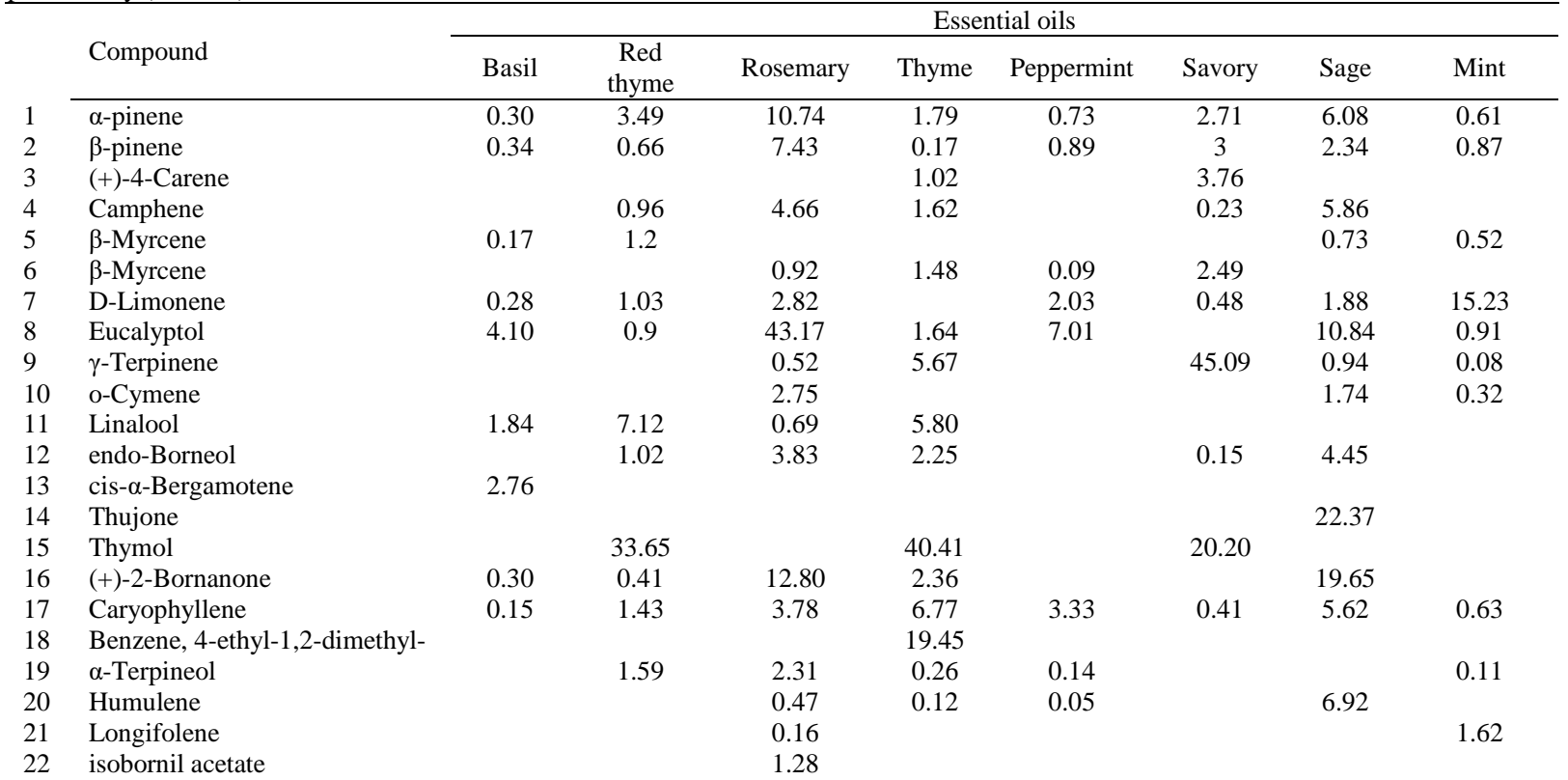




\begin{tabular}{|c|c|c|c|c|c|c|c|c|}
\hline 23 & terpinen-4-ol & & 0.13 & 0.46 & 2.16 & & 0.44 & 0.23 \\
\hline 24 & Estragole & 84.89 & & 0.29 & & & & \\
\hline 25 & $\beta$-thujone & & & & & & 6.58 & \\
\hline 26 & menthofuran & & & & 1.62 & & & \\
\hline 27 & menthone & & & & 22.51 & & & \\
\hline 28 & p-menthone & & & & 4.22 & & & 0.65 \\
\hline 29 & menthol & & & & 6.30 & & & \\
\hline 30 & Levomenthol & 0.10 & & & 44.94 & & & \\
\hline 31 & p-Cymene & & & & & 19.64 & & \\
\hline 32 & Bornyl acetate & 0.20 & & & 0.16 & & 2.29 & \\
\hline 33 & (-)-Carvone & & & & & & & 72.62 \\
\hline 34 & o-xylene & & 43.85 & & & & & \\
\hline
\end{tabular}

\section{Antifungal activity of essential oils}

The antifungal activity of eight essential oils against seven strains of $P$. commune was determined, using micro-atmosphere method (625 $\mu \mathrm{L} . \mathrm{L}^{-1}$ of air). Five essential oils: thyme, red thyme (Thymus vulgaris L.), peppermint (Mentha piperita L.), mint (Mentha crispate L.) savory (Satureja hortensis L.) mint (Mentha piperita L.), completely inhibited the growth of all strains during cultivation at $25{ }^{\circ} \mathrm{C}$ and $5{ }^{\circ} \mathrm{C}$. Other essential oils: basil (Oscimum basilicum L.), rosemary (Rosmarinus officinalis L), and sage (Salvia officinalis L.) (Tab 3) have different effects on the growth of $P$. commune strains. Inhibitory effect ( $\mathrm{P}$ $<0.001$ ) on the growth of the all strains of $P$. commune was recorded in all essential oils. Significant differences were observed between the individual strains (Table 3), which are documented in Figure 1, too.

Table 3 Effect of essential oils (treatment) and strains on the growth of Penicillium commune

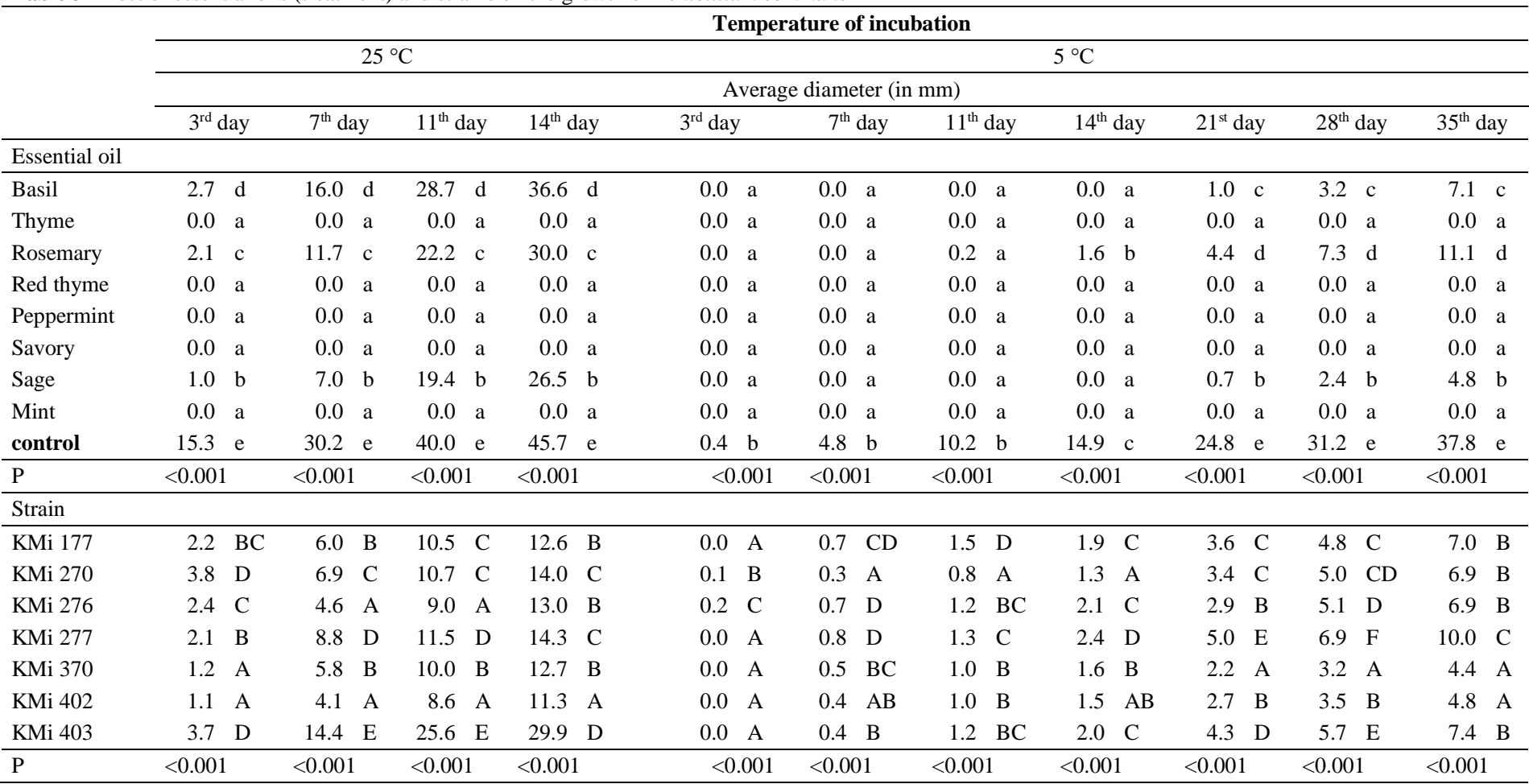

Legend: Averages followed by the same letter (in columns) is not statistical different at $\alpha=0.05$ (ANOVA, Tukey test) small letters - difference within treatment, capital letters - different within strains.

Interaction Plot on 35th day at $5^{\circ} \mathrm{C}$

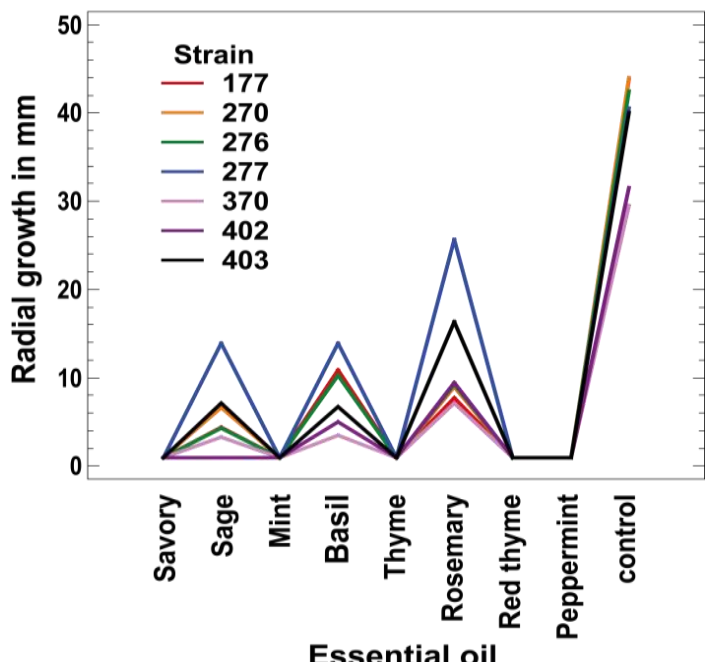

Essential oil

Figure 1 Growth of strains of $P$. commune on the $35^{\text {th }}$ day of incubation at $5{ }^{\circ} \mathrm{C}$ in the presence/absence of essential oil
All strains of $P$. commune, without essential oil at the atmosphere - controls, were grown on the first measurement $\left(3^{\text {rd }}\right.$ day of incubation) at $25^{\circ} \mathrm{C}$. Dairy products are stored at low temperatures, so an additional cultivation temperature of $5{ }^{\circ} \mathrm{C}$ was used. At $5{ }^{\circ} \mathrm{C}$ (controls), the growth of two strains (KMi 270 and KMi 276) was recorded on the $3^{\text {rd }}$ day and other five strains on the $7^{\text {th }}$ day. Inhibition of mycelial growth (percentage of inhibition) is shown in Figure 2. Thyme, red thyme, savory, peppermint, and mint essential oils completely inhibited the growth of the strains of $P$. commune at $5{ }^{\circ} \mathrm{C}$, respectively $25{ }^{\circ} \mathrm{C}$, throughout the experiment. Basil, rosemary, and sage essential oils inhibited the growth of the strains of $P$. commune, but their inhibition effects were depending on the individual strains. Sage essential oil $100 \%$ inhibited the growth of the strain $P$. commune $\mathrm{KMi} 402$ at $5{ }^{\circ} \mathrm{C}$, for example. The stimulation effect was observed in one case. Basil essential oil stimulated growth of P. commune KMi 277 (Fig 2g) at the $14^{\text {th }}$ day of incubation at $25{ }^{\circ} \mathrm{C}$. Strong inhibition effect $(100 \%)$ of thyme and mint determined Císarová et al. (2016b) on Aspergillus flavus and Aspergillus parasiticus. Thyme oil $\left(625 \mu \mathrm{L} . \mathrm{L}^{-1}\right.$ of air) totally inhibited growth of Aspergillus niger and Aspergillus tubingensis (Císarová et al. 2016a). The 100 $\%$ inhibition effect of thyme, red thyme, mint, and savory essential oils (625 $\mu \mathrm{L}^{\mathrm{L}} \mathrm{L}^{-1}$ of air) against Rhizopus spp. has shown Tančinová et al. (2018). According Elshafie et al. (2015), thyme essential oils can be utilized against Monilinia laxa, Monilinia fructigena, and Monilinia fructicola. Alizadeh-Saltech et al. (2010) tested the influence of vapor phase of sage, savory, and zataria essential oils on the growth of Rhizopus stolonifer. Sterile filter paper discs soaked with $3,6,12,24$ or $48 \mu$ pure essential oils were placed on the inner 
surface of the Petri dish lid. Sage oil did not have an acceptable inhibitory effect on the $R$. stolonifer. Savory, and zataria, but showed strong antifungal activity against $R$. stolonifer. The $100 \%$ inhibitory effect of the savory essential oil and the partial inhibitory effect of sage essential oil have been observed in our experiment, too. Servili et al. (2017) recommended exposure to volatiles of the rosemary and peppermint essential oils an innovative method to control the postharvest gray mold of table grapes. Sarkhosh et al. (2017) tested the inhibitory properties of five essential oils: mint, savory, thyme, cinnamon, and lavender against anthracnose (Colletotrichum gloesporioides Penz) of avocado fruit. Authors report the potential of using savory and thyme essential oils as biological fungicides for increasing the storage time of avocado fruit. Thyme oil highly reduced $64 \%$ of Botrytis cinerea colonization on pretreated detached leaves of tomato compared to untreated control (Ben-Jabeur, et al., 2015) Combrinck et al. (2011) tested antifungal properties of eighteen essential oils (including peppermint and thyme oils) on the fungal growth of five plant pathogens (Lasiodiplodia theobromae, Colletotrichum gloesporioides, Alternaria citri, Botrytis cinerea, and Penicillium digitatum). Thyme oil proved to be the most effective inhibitor, totally inhibiting all of the pathogens tested at concentrations of $1000 \mu 1.1^{-1}$ (medium) and lower, with the exception of resistant Penicillium strains. The concrete essential oil can have different influence on the growth of species of molds. It is very individual. In our research, we noticed differences between the tested strains within $P$. commune. Therefore, it is necessary to use more strains of the same species in the trials so that the results are not influenced by the individual attributes of the concrete strain.
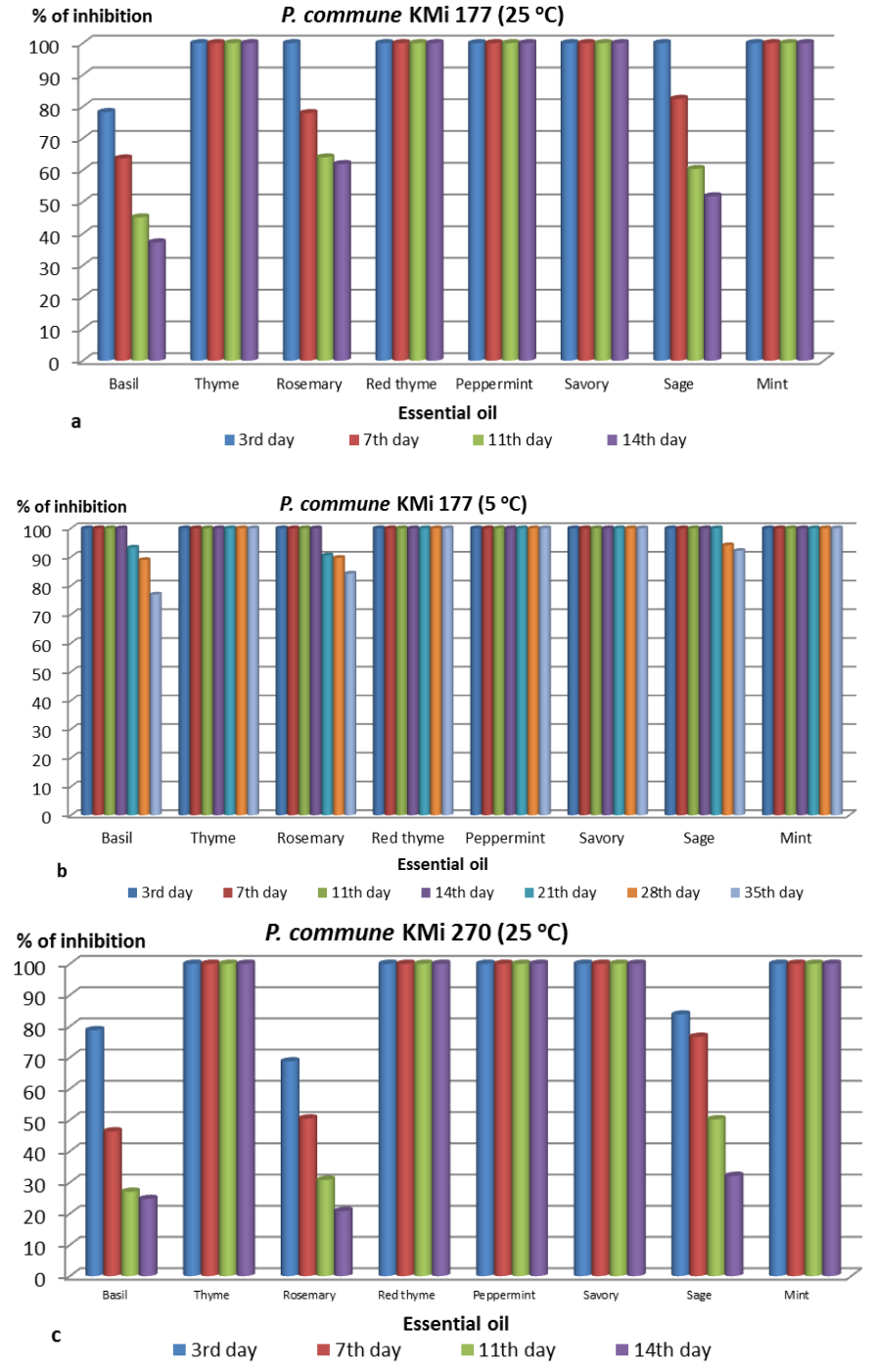
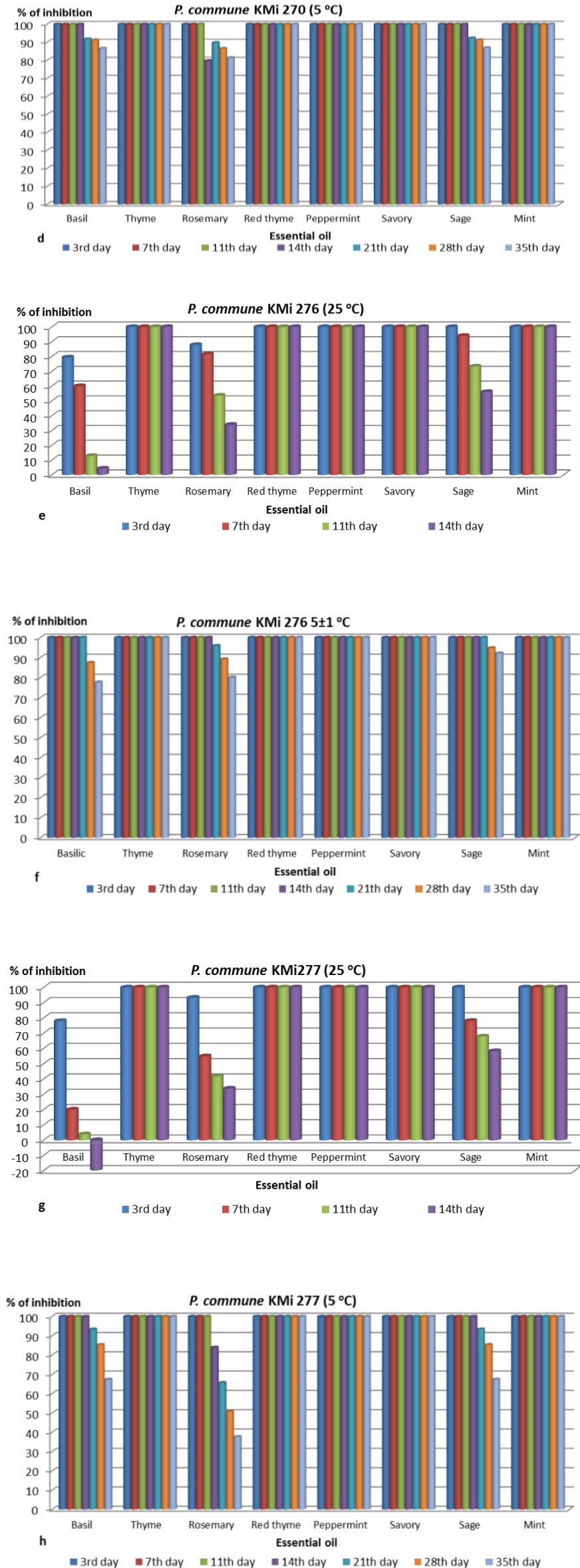

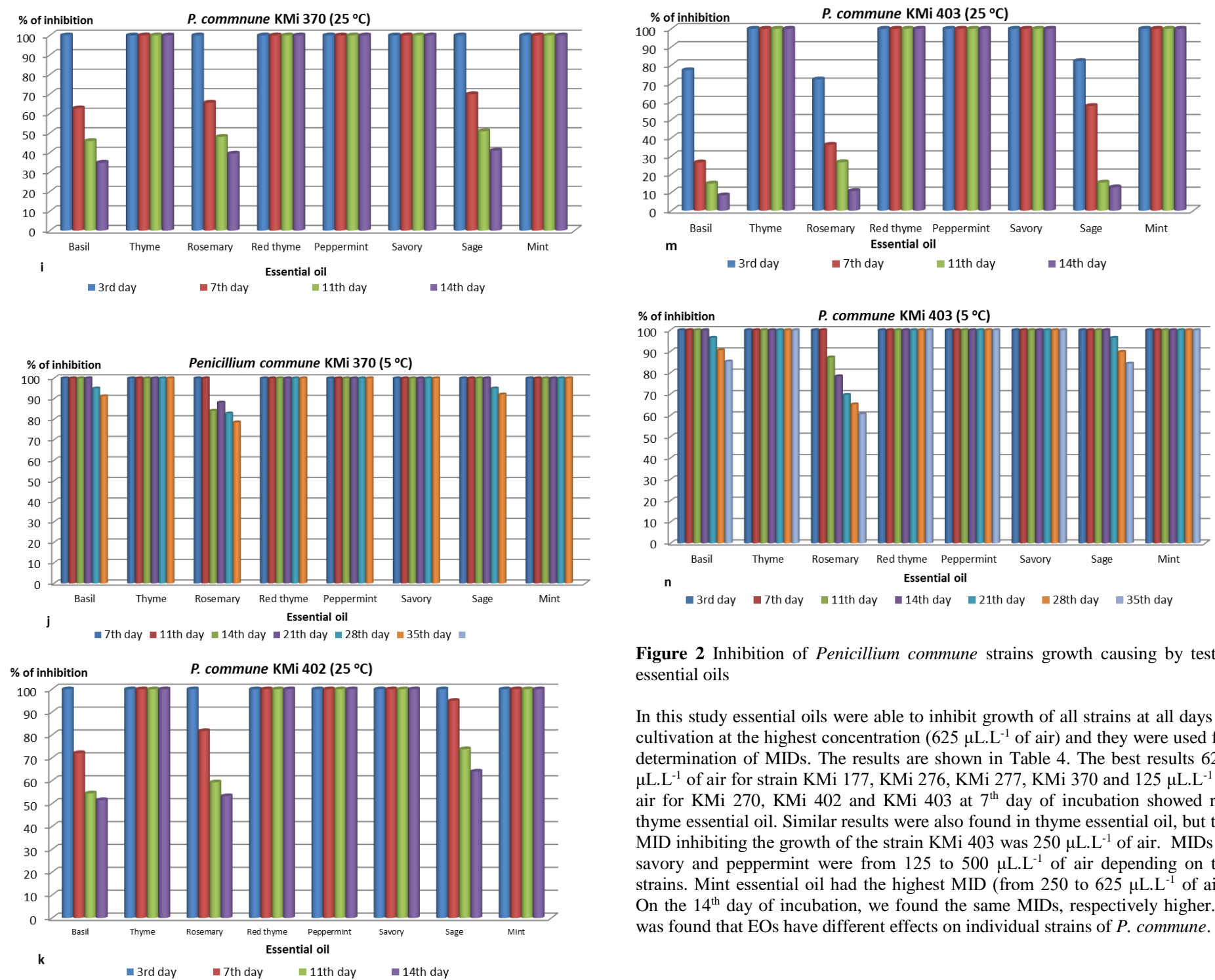

Figure 2 Inhibition of Penicillium commune strains growth causing by tested essential oils

In this study essential oils were able to inhibit growth of all strains at all days of cultivation at the highest concentration $\left(625 \mu \mathrm{L} . \mathrm{L}^{-1}\right.$ of air) and they were used for determination of MIDs. The results are shown in Table 4 . The best results 62.5 $\mu \mathrm{L} . \mathrm{L}^{-1}$ of air for strain KMi 177, KMi 276, KMi 277, KMi 370 and $125 \mu$ L.L $\mathrm{L}^{-1}$ of air for KMi 270, KMi 402 and KMi 403 at $7^{\text {th }}$ day of incubation showed red thyme essential oil. Similar results were also found in thyme essential oil, but the MID inhibiting the growth of the strain KMi 403 was $250 \mu \mathrm{L} . \mathrm{L}^{-1}$ of air. MIDs of savory and peppermint were from 125 to $500 \mu \mathrm{L} . \mathrm{L}^{-1}$ of air depending on the strains. Mint essential oil had the highest MID (from 250 to $625 \mu \mathrm{L} . \mathrm{L}^{-1}$ of air) On the $14^{\text {th }}$ day of incubation, we found the same MIDs, respectively higher. It was found that EOs have different effects on individual strains of P. commune.

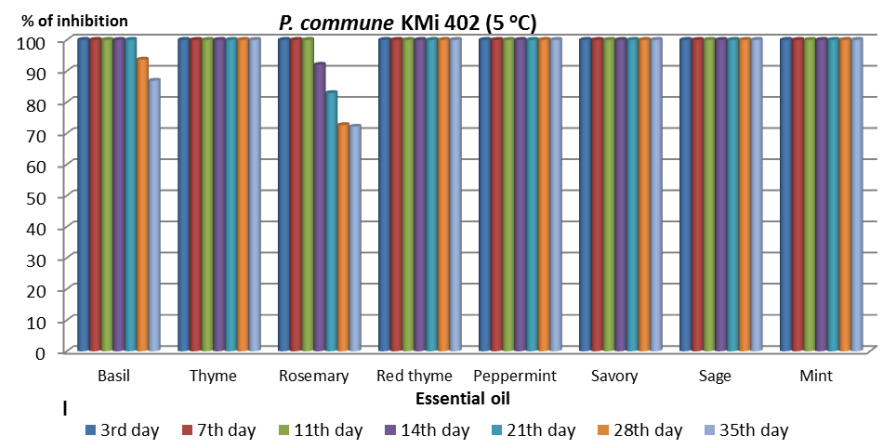

Table 4 The growth (in \%) of colonies ( $\mathrm{n}=6)$ of Penicillium commune on CYA at $25{ }^{\circ} \mathrm{C}$ after 7 and, respectively, 14 days of cultivation after application of essential oils

\begin{tabular}{|c|c|c|c|c|c|c|c|c|c|c|c|c|c|c|c|}
\hline \multirow{4}{*}{$\begin{array}{l}\text { Essential } \\
\text { oil }\end{array}$} & \multirow{4}{*}{$\begin{array}{l}\mu \mathrm{L} . \mathrm{L}^{-1} \\
\text { of air }\end{array}$} & \multicolumn{14}{|c|}{ Strain of Penicillium commune } \\
\hline & & \multicolumn{2}{|c|}{ KMi 177} & \multicolumn{2}{|c|}{ KMi 270} & \multicolumn{2}{|c|}{ KMi 276} & \multicolumn{2}{|c|}{ KMi 277} & \multicolumn{2}{|c|}{ KMi 370} & \multicolumn{2}{|c|}{ KMi 402} & \multicolumn{2}{|c|}{ KMi 403} \\
\hline & & \multicolumn{14}{|c|}{ Day of cultivation } \\
\hline & & 7th & 14th & 7th & 14th & 7 th & 14th & 7th & 14th & 7th & 14th & 7th & 14th & 7th & 14th \\
\hline \multirow{7}{*}{ Thyme } & 625 & 0 & 0 & 0 & 0 & 0 & 0 & 0 & 0 & 0 & 0 & 0 & 0 & 0 & 0 \\
\hline & 500 & 0 & 0 & 0 & 0 & 0 & 0 & 0 & 0 & 0 & 0 & 0 & 0 & 0 & 0 \\
\hline & 250 & 0 & 0 & 0 & 0 & 0 & 0 & 0 & 0 & 0 & 0 & 0 & 0 & 0 & 0 \\
\hline & 125 & 0 & 0 & 0 & 0 & 0 & 0 & 0 & 0 & 0 & 0 & 0 & 0 & 100 & 100 \\
\hline & 62.5 & 50 & 50 & 100 & 100 & 66.66 & 100 & 100 & 100 & 0 & 0 & 66.66 & 83.33 & 100 & 100 \\
\hline & 31.3 & 100 & 100 & 100 & 100 & 100 & 100 & 100 & 100 & 100 & 100 & 100 & 100 & 100 & 100 \\
\hline & 15.6 & 100 & 100 & 100 & 100 & 100 & 100 & 100 & 100 & 100 & 100 & 100 & 100 & 100 & 100 \\
\hline
\end{tabular}




\begin{tabular}{|c|c|c|c|c|c|c|c|c|c|c|c|c|c|c|c|}
\hline \multirow{7}{*}{ Red thyme } & 625 & 0 & 0 & 0 & 0 & 0 & 0 & 0 & 0 & 0 & 0 & 0 & 0 & 0 & 0 \\
\hline & 500 & 0 & 0 & 0 & 0 & 0 & 0 & 0 & 0 & 0 & 0 & 0 & 0 & 0 & 0 \\
\hline & 250 & 0 & 0 & 0 & 0 & 0 & 0 & 0 & 0 & 0 & 0 & 0 & 0 & 0 & 0 \\
\hline & 125 & 0 & 0 & 0 & 0 & 0 & 0 & 0 & 0 & 0 & 0 & 0 & 0 & 0 & 0 \\
\hline & 62.5 & 0 & 50 & 100 & 100 & 0 & 33.33 & 0 & 0 & 0 & 0 & 50 & 66.66 & 16.66 & 16.66 \\
\hline & 31.3 & 100 & 100 & 100 & 100 & 66.66 & 83.33 & 100 & 100 & 83.33 & 83.33 & 100 & 100 & 100 & 100 \\
\hline & 15.6 & 100 & 100 & 100 & 100 & 100 & 100 & 100 & 100 & 100 & 100 & 100 & 100 & 100 & 100 \\
\hline \multirow{7}{*}{ Peppermint } & 625 & 0 & 0 & 0 & 0 & 0 & 0 & 0 & 0 & 0 & 0 & 0 & 0 & 0 & 0 \\
\hline & 500 & 0 & 0 & 0 & 0 & 0 & 0 & 0 & 0 & 0 & 33.33 & 0 & 0 & 0 & 0 \\
\hline & 250 & 0 & 0 & 0 & 66.66 & 0 & 33.33 & 0 & 0 & 33.33 & 100 & 0 & 83.33 & 66.66 & 83.33 \\
\hline & 125 & 0 & 50 & 100 & 100 & 66.66 & 83.33 & 0 & 66.66 & 100 & 100 & 100 & 100 & 100 & 100 \\
\hline & 62.5 & 100 & 100 & 100 & 100 & 100 & 100 & 100 & 100 & 100 & 100 & 100 & 100 & 100 & 100 \\
\hline & 31.3 & 100 & 100 & 100 & 100 & 100 & 100 & 100 & 100 & 100 & 100 & 100 & 100 & 100 & 100 \\
\hline & 15.6 & 100 & 100 & 100 & 100 & 100 & 100 & 100 & 100 & 100 & 100 & 100 & 100 & 100 & 100 \\
\hline \multirow{7}{*}{ Savory } & 625 & 0 & 0 & 0 & 0 & 0 & 0 & 0 & 0 & 0 & 0 & 0 & 0 & 0 & 0 \\
\hline & 500 & 0 & 0 & 0 & 0 & 0 & 0 & 0 & 0 & 0 & 0 & 0 & 0 & 0 & 0 \\
\hline & 250 & 0 & 0 & 0 & 0 & 0 & 0 & 0 & 0 & 0 & 0 & 0 & 0 & 33.33 & 33.33 \\
\hline & 125 & 0 & 0 & 33.33 & 66.66 & 0 & 33.33 & 66.66 & 66.66 & 100 & 100 & 66.66 & 100 & 50 & 100 \\
\hline & 62.5 & 100 & 100 & 100 & 100 & 66.66 & 66.66 & 100 & 100 & 100 & 100 & 100 & 100 & 100 & 100 \\
\hline & 31.3 & 100 & 100 & 100 & 100 & 100 & 100 & 100 & 100 & 100 & 100 & 100 & 100 & 100 & 100 \\
\hline & 15.6 & 100 & 100 & 100 & 100 & 100 & 100 & 100 & 100 & 100 & 100 & 100 & 100 & 100 & 100 \\
\hline \multirow{7}{*}{ Mint } & 625 & 0 & 0 & 0 & 0 & 0 & 0 & 0 & 0 & 0 & 0 & 0 & 0 & 0 & 0 \\
\hline & 500 & 0 & 0 & 0 & 0 & 0 & 0 & 0 & 0 & 0 & 0 & 0 & 0 & 50 & 66.66 \\
\hline & 250 & 0 & 0 & 0 & 50 & 16.66 & 16.66 & 0 & 100 & 0 & 16.66 & 0 & 33.33 & 100 & 100 \\
\hline & 125 & 100 & 100 & 100 & 100 & 100 & 100 & 100 & 100 & 100 & 100 & 100 & 100 & 100 & 100 \\
\hline & 62.5 & 100 & 100 & 100 & 100 & 100 & 100 & 100 & 100 & 100 & 100 & 100 & 100 & 100 & 100 \\
\hline & 31.3 & 100 & 100 & 100 & 100 & 100 & 100 & 100 & 100 & 100 & 100 & 100 & 100 & 100 & 100 \\
\hline & 15.6 & 100 & 100 & 100 & 100 & 100 & 100 & 100 & 100 & 100 & 100 & 100 & 100 & 100 & 100 \\
\hline
\end{tabular}

Legend: CYA - Czapek yeast extract agar

Using probit analysis, predicted MIDs90 and MIDs50 were calculated. The results are shown in Table 5. The most effective tested essential oils were red thyme and thyme, less effective peppermint and savory. MIDs of mint essential oil were the highest. The most resistant strain was KMi 403 with the highest MID90 for thyme, peppermint, savory, and mint essential oils. The highes MID90 of red thyme was determinate for KMi 270. Radaelli et al. (2016) tested antimicrobial activities of six essential oils (basil, rosemary, peppermint, marjoram, and thyme) against Clostridium perfringens. The essential oil from Thymus vulgaris showed the lowest MIC (minimum inhibitory concentration) against Clostridium perfringens. The authors, as well as our research showed a significant antimicrobial activity of thyme essential oil.

$\underline{\text { Table } 5 \text { Minimal inhibition doses estimated by probit analyses }}$

\begin{tabular}{|c|c|c|c|c|c|c|c|c|c|c|c|}
\hline \multirow{4}{*}{$\begin{array}{l}\text { Strain of } \\
\text { P. commune }\end{array}$} & \multirow{4}{*}{ MID } & \multicolumn{10}{|c|}{ Essential oil } \\
\hline & & \multicolumn{2}{|c|}{ Thyme } & \multicolumn{2}{|c|}{ Red thyme } & \multicolumn{2}{|c|}{ Peppermint } & \multicolumn{2}{|c|}{ Savory } & \multicolumn{2}{|c|}{ Mint } \\
\hline & & & & & & & & & & & \\
\hline & & 7 & 14 & 7 & 14 & 7 & 14 & 7 & 14 & 7 & 14 \\
\hline \multirow{2}{*}{ KMi 177} & MID90 & 74.24 & 74.94 & 53.46 & 74.94 & 104.85 & 143.92 & 104.85 & 105.03 & 211.10 & 211.11 \\
\hline & MID50 & 62.51 & 63.02 & 46.93 & 63.02 & 94.06 & 125.00 & 94.06 & 94.31 & 193.74 & 193.75 \\
\hline \multirow{2}{*}{ KMi 270} & MID90 & 104.85 & 105.03 & 104.85 & 105.03 & 211.10 & 294.02 & 136.48 & 153.07 & 211.10 & 280.37 \\
\hline & MID50 & 94.06 & 94.31 & 94.07 & 94.31 & 193.74 & 261.07 & 119.19 & 132.06 & 193.74 & 250.00 \\
\hline \multirow{2}{*}{ KMi 276} & MID90 & 80.29 & 105.03 & 42.57 & 78.36 & 153.23 & 305.97 & 80.29 & 153.48 & 256.22 & 256.22 \\
\hline & MID50 & 66.99 & 94.31 & 34.16 & 53.70 & 132.10 & 213.83 & 66.99 & 100.02 & 230.86 & 230.87 \\
\hline \multirow{2}{*}{ KMi 277} & MID90 & 104.85 & 105.03 & 53.47 & 53.71 & 104.85 & 153.07 & 153.23 & 153.07 & 211.10 & 393.29 \\
\hline & MID50 & 94.07 & 94.31 & 46.93 & 47.06 & 94.07 & 132.06 & 132.10 & 132.06 & 193.74 & 365.34 \\
\hline \multirow{2}{*}{ KMi 370} & MID90 & 53.47 & 53.71 & 46.92 & 46.76 & 268.70 & 524.25 & 211.10 & 211.11 & 211.10 & 256.22 \\
\hline & MID50 & 46.93 & 47.06 & 38.00 & 37.80 & 240.54 & 487.72 & 193.74 & 193.75 & 193.74 & 230.87 \\
\hline \multirow{2}{*}{ KMi 402} & MID90 & 80.29 & 89.43 & 74.24 & 81.06 & 211.10 & 314.06 & 153.23 & 211.11 & 211.10 & 268.70 \\
\hline & MID50 & 66.99 & 74.37 & 62.52 & 67.56 & 193.74 & 277.56 & 132.10 & 193.75 & 193.74 & 240.54 \\
\hline \multirow{2}{*}{ KMi 403} & MID90 & 211.11 & 211.11 & 65.32 & 65.32 & 294.02 & 314.06 & 295.74 & 300.70 & 533.37 & 540.97 \\
\hline & MID50 & 193.75 & 193.75 & 55.95 & 55.95 & 261.08 & 277.56 & 186.87 & 240.54 & 500.00 & 510.31 \\
\hline
\end{tabular}

Legend: P. - Penicillium, MID - minimum inhibitory doses

In our research, we have confirmed the ability of the tested oils family Lamiaceae to inhibit (partially or completely) the growth of $P$. commune strains. The strains used in our experiment were isolated directly from the moldy dairy products produced in Slovakia. However, the individual strains responded differently on the same oil, and therefore it necessary to use more than one strain in research. Testing should be supplemented by testing the influence of oils on the sensory properties of foods. According to Servilli et al. (2017), the interaction of food matrix components with the essential oils need to be investigated before their application is proposed for commercial practice. A challenge for the application of essential oils is their strong aroma even at low concentrations, which might adversely affect the organoleptic properties of the food being treated Concentration of these substances applied in cheeses should be considered carefully because of their possible negative impacts on organoleptic properties (Khorshidian et al., 2018).

\section{CONCLUSION}

In this study, we evaluated the antifungal properties of basil (Oscimum basilicum L.), rosemary (Rosmarinus officinalis L.), thyme, red thyme (Thymus vulgaris L.), mint (Mentha crispate L.), peppermint (Mentha piperita L.), savory (Satureja 
hortensis L.), and sage (Salvia officinalis L.) essential oils. Five essential oils: thyme, red thyme, peppermint, mint, and savory completely inhibited the growth of all strains during cultivation at $25^{\circ} \mathrm{C}$ and $5{ }^{\circ} \mathrm{C}$ also. Other essential oils: basil, rosemary, and sage have different effects on the growth of $P$. commune strains. Essential oils that completely inhibit the growth of all strains were used to determine their minimum inhibitory doses (MIDs). The best results $62.5 \mu \mathrm{L}^{-\mathrm{L}^{-1}}$ of air and $125 \mu \mathrm{L} . \mathrm{L}^{-1}$ of air $7^{\text {th }}$ day at $25{ }^{\circ} \mathrm{C}$ of incubation showed red thyme essential oil. Similar results were also found in thyme essential oil, but the MID inhibiting the growth of the one strain was $250 \mu \mathrm{L}^{-\mathrm{L}^{-1}}$ of air. MIDs of savory and peppermint were from 125 to $500 \mu \mathrm{L} . \mathrm{L}^{-1}$ of air depending on the strains. Mint essential oil had the highest MID (from 250 to $625 \mu \mathrm{L} . \mathrm{L}^{-1}$ of air). On the $14^{\text {th }}$ day of incubation we found the same MIDs, respectively higher. It was found that essential oils have different effects on individual strains of $P$. commune. According to probit analyses, the most effective tested essential oils were red thyme and thyme, less effective peppermint and savory. MIDs of mint essentia oil were the highest. The most resistant strain was KMi 403 with the highest MID90 for thyme, peppermint, savory, and mint essential oils. The highest MID90 of red thyme was determinate for KMi 270.

Acknowledgments: This work was supported by APVV-15-0543, KEGA 015SPU-4/2018 and Research Center AgroBioTech built in accordance with the project Building Research Centre „AgroBioTech" ITMS 26220220180. The authors thank Eva Čunderlíková for her responsible approach in the preparation and realization of the experiment.

\section{REFERENCES}

ALIZADEH-SALTEH, S., ARZANI, K., OMIDBEILI, R., SAFAIE, N. 2010. Essential oils inhibit mycelial growth of Rhizopus stolonifer. European Journa of Horticurtural Science, 75(6), 278-282.

BASSANETTI, I., CARCELli, M., BUSCHINI, A., MONTALBANO, S., LEONARDI, G., PELAGATTI, P., TOSI, G., FIORENTINI, L., ROGOLINO, D. 2017. Investigation of antibacterial activity of new classes of essential oils $\begin{array}{llll}\text { derivatives. } & \text { Food } & \text { Control, } & \text { 606-612 }\end{array}$ https://doi.org/10.1016/j.foodcont.2016.09.010

BEN FARHAT, M., JORDÁN, M. J., CHAOUCH-HAMADA, R., LANDOULSI, A., SOTOMAYOR, J. A. 2016. Phenophase effects on sage (Salvia officinalis L.) yield and composition of essential oil. Journal of Applied Research on Medicinal and Aromatic Plants, 3(3), 87-93. https://doi.org/10.1016/j.jarmap.2016.02.001

BEN-JABEUR, M., GHABRI, E., MYRIAM, M., HAMADA, W. 2015. Thyme essential oil as a defense inducer of tomato against gray mold and Fusarium wilt Plant Physiology and Biochemistry, 94, 35-40. https://doi.org/10.1016/j.plaphy.2015.05.006

CAKIR, A., KORDALI, S., KILIC, H., KAYA, E. 2005. Antifungal properties of essential oil and crude extracts of Hypericum linarioides Bosse. Biochemical $\begin{array}{llll}\text { Systematics } \quad \text { Ecology, 33(3), p. 245-256. } & \text {. }\end{array}$ https://doi.org/10.1016/j.bse.2004.08.006

CHEONG, E. Y. L., SANDHU, A., JAYABALAN, J., KIEU LE, T. T., NHIEP N. T., MY HO, H. T., ZWIELEHNER, J., BANSAL, N., TURNER, M. S. 2014 Isolation of lactic acid bacteria with antifungal activity against the common cheese spoilage mould Penicillium commune and their potential as biopreservatives in cheese. Food Control, 46, 91-97. https://doi.org/10.1016/j.foodcont.2014.05.011

CÍSAROVÁ, M., TANČINOVÁ, D., MEDO, J. 2016a. Antifungal activity of lemon, eucalyptus, thyme, oregano, sage and lavender essential oils against Aspergillus niger and Aspergillus tubingensis isolated from grapes. Potravinarstvo Slovak Journal of Food Science, 10(1), 83-88 https://doi.org/10.5219/554

CÍSAROVÁ, M., TANČINOVÁ, D., MEDO, J., KAČÁNIOVÁ, M. 2016b. The in vitro effect of selected essential oils on the growth and mycotoxin production of Aspergillus species. Journal of Environmental Science and Health, Part B 51(10), $\quad$ 668-674. $\quad$ https://doi.org/10.1080/03601234.2016.1191887 DUŠKOVÁ, E., DUŠEK, K., INDRÁK, P., SMÉKALOVÁ, K. 2016 Postharvest changes in essential oil content and quality of lavender flowers. Industrial Crops and Products, vol. 79, p. 225-231. https://doi.org/10.1016/j.indcrop.2015.11.007

COMBRINCK, S., REGNIER, T., KAMATOU, G. P. P. 2011. In vitro activity of eighteen essential oils and some major components against common postharvest fungal pathogens of fruit. Industrial Crops and Products, 33(2), 344349. https://doi.org/10.1016/j.indcrop.2010.11.011

ELSHAFIE, H. S., MANCINI, E., CAMELE, I., MARTINO, L. D., DE FEO, V 2015. In vivo antifungal activity of two essential oils from Mediterranean plants against postharvest brown rot disease of peach fruit. Industrial Crops and Products, 66, 11-15. https://doi.org/10.1016/j.indcrop.2014.12.031

GARNIER, L., VALENCE, F., PAWTOWSKI, A., AUHUSTSINAVAGALERNE, L., FROTTÉ, N., BARONCELli, R., VALENCE, F., COTON, E., MOUNIER, J. 2017. Diversity of spoilage fungi associated with various French dairy products. International Journal of Food Microbiology, 241, 191-197. https://doi.org/10.1016/j.ijfoodmicro.2016.10.026
GUYNOT, M. E., RAMOS, A. J., SETO, L., PURROY, P., SANCHIS, V., MARIN, S. 2003. Antifungal activity of volatile compounds generated by essential oils against fungi commonly causing deterioration of bakery products Journal of Applied Microbiology, 94(5), 893-899. https://doi.org/10.1046/j.1365 2672.2003.01927.x

KHORSHIDIANAB, N., YOUSEFIAB, M., KHANNIRIA, E., MOHAMMAD MORTAZAVIAN, A. 2018. Potential application of essential oils as antimicrobial preservatives in cheese. Innovative Food Science \& Emerging Technologies, 45, 62-72. https://doi.org/10.1016/j.ifset.2017.09.020

KOCIC-TANACKOV, S. D., DIMIC, G. R., MOJOVIĆ, L. V., PEJIN, J. D., TANACKOV, I. J. 2014. Effect of caraway, basil, and oregano extracts and their binary mixtures on fungi in growth medium and on shredded cabbage. $L W T$ Food Science and Technology, 59(1), 426-432. https://doi.org/10.1016/j.lwt.2014.05.023

KORDALI, S., CAKIR, A., OZER, H., CAKMAKCI, R., KESDEK, M., METE E. 2008. Antifungal, phytotoxic and insecticidal properties of essential oil isolated from Turkish Origanum acutidens and its three components, carvacrol, thymol and p-cymene. Bioresource Technology, 99(18), 8788-8795 https://doi.org/10.1016/j.biortech.2008.04.048

KURE, C., WASTESON, Y., BRENDEHAUG, J., SKAAR, I. 2001. Mould contaminants on Jarlsberg and Norvegia cheese blocks from four factories. International Journal of Food Microbiology, 70(1-2), 21-27. https://doi.org/10.1016/s0168-1605(01)00520-7

KURE, C.F., SKAAR, I. 2000. Mould growth on the Norwegian semi-hard cheeses Norvegia and Jarlsberg. International Journal of Food Microbiology, 62(1-2), 133-137. https://doi.org/10.1016/s0168-1605(00)00384-6

LUND, F., FILTENBORG, O., FRISVAD, J.C. 1995. Associated mycoflora of cheese. Food Microbiology, 12, 173-180. https://doi.org/10.1016/s07400020(95)80094-8

LUND, F., NIELSEN, A.B., SKOUBOE, P. 2003. Distribution of Penicillium commune isolates in cheese dairies mapped using secondary metabolite profiles, morphotypes, RAPD and AFLP fingerprinting. Food Microbiology, 20 (6), 725734. https://doi.org/10.1016/s0740-0020(02)00160-0

MÉNDEZ-TOVAR, I., NOVAK, J., SPONZA, S., HERRERO, B., ASENSIO-S MANZANERA, M. C. 2016. Variability in essential oil composition of wild populations of Labiatae species collected in Spain. Industrial Crops and Products, 79, 18-28. https://doi.org/10.1016/j.indcrop.2015.10.009

PITT, J. I., HOCKING, A. D. 2009. Fungi and food spoilage. 3rd ed. London, New York : Springer Science \& Business Media, LLC, 519 p. ISBN 978-0-38792206-5.

RADAELlI, M., DA SILVA, B. P., WEIDLICH, L., HOEHNE, L., FLACH, A. DA COSTA, L. A. M. A., ETHUR, E. M. 2016. Antimicrobial activities of six essential oils commonly used as condiments in Brazil against Clostridium perfringens. Brazilian Journal of Microbiology, 47(2), 424-430. https://doi.org/10.1016/j.bjm.2015.10.001

RAUT, J. S., KARUPPAYIL, S. M. 2014. A status review on the medicinal properties of essential oils. Industrial Crops and Products, 62, 250-264 https://doi.org/10.1016/j.indcrop.2014.05.055

SARKHOSH, A., VARGAS, A. I., SCHAFFER, B., PALMATEER, A. J., LOPEZ, P., SOLEYMANI, A., FARZANEH, M. 2017. Postharvest management of anthracnose in avocado (Persea americana Mill.) fruit with plant-extracted oils. Food Packaging and Shelf Life, 12, 16-22. https://doi.org/10.1016/j.fps1.2017.02.001

SERVILI, A., FELIZIANI, E., ROMANAZZI, G. 2017. Exposure to volatiles of essential oils alone or under hypobaric treatment to control postharvest gray mold of table grapes. Postharvest Biology and Technology, 133, 36-40 https://doi.org/10.1016/j.postharvbio.2017.06.007

TANČINOVÁ, D., MAŠKOVÁ, Z., FOLTINOVÁ, D., ŠTEFÁNIKOVÁ, J., ÁRVAY, J. 2018. Effect of essential oils of Lamiaceae plants on the Rhizopus spp. Potravinarstvo Slovak Journal of Food Sciences, 12(1), p. 491-498. https://doi.org/10.5219/921 